\title{
The first record of the pantropical anthropochore millipede, Cylindrodesmus birsutus Pocock, 1889, from Cameroon (Diplopoda: Polydesmida: Haplodesmidae)
}

\section{Первая находка пантропической антропохорной многоножки Cylindrodesmus birsutus Pocock, 1889 в Камеруне (Diplopoda: Polydesmida: Haplodesmidae)}

\author{
S.I. Golovatch ${ }^{1}$, A.R. Nzoko Fiemapong ${ }^{2}$, D. VandenSpiegel ${ }^{3}$ \\ С.И. Головач ${ }^{1}$, А.Р. Нзоко Фьемапонг ${ }^{2}$, А. ВанденШпигель ${ }^{3}$
}

\footnotetext{
${ }^{1}$ Institute for Problems of Ecology and Evolution, Russian Academy of Sciences, Leninsky prospekt 33, Moscow 119071 Russia.

${ }^{1}$ Институт проблем экологии и эволюции РАН, Ленинский пр-т, 33, Москва 119071 Россия.

${ }^{2}$ Laboratoire de Zoologie, Université Yaoundé 1, BP 812, Cameroun.

${ }^{3}$ Musée Royal de l'Afrique Centrale, B-3480 Tervuren, Belgique.
}

KEY WORDS: millipede, Haplodesmidae, Cylindrodesmus hirsutus, pantropical, introduction, parthenogenesis, Cameroon.

КЛЮЧЕВЫЕ СЛОВА: диплопода, Haplodesmidae, Cylindrodesmus hirsutus, пантропический, интродукция, партеногенез, Камерун.

ABSTRACT. The first formal record of the pantropical millipede, Cylindrodesmus hirsutus Pocock, 1889, is given from Cameroon. The species seems to be restricted to a man-made palm plantation within the capital city of Yaoundé, apparently being represented by a bisexual population. A male is richly illustrated to confirm the identity.

РЕЗЮМЕ. Приведена первая формальная находка пантропической многоножки Cylindrodesmus hirsutus Pocock, 1889 в Камеруне. Вид, вероятно, приурочен к рукотворной пальмовой плантации в столице Яунде, будучи представлен, очевидно, обоеполой популяцией. Даны многочисленные иллюстрации самца для подтверждения видовой принадлежности.

\section{Introduction}

The millipede Cylindrodesmus hirsutus Pocock, 1889, is among the few that show a truly pantropical distribution in the entire class Diplopoda. According to the latest review of Cylindrodesmus Pocock, 1889 [Golovatch et al., 2001], this genus encompasses only two species: $C$. hirsutus and C. villosus Pocock, 1898. Since its description from Christmas Island, Indian Ocean, C. hirsutus (or its numerous synonyms) has been reported either by bisexual or parthenogenetic populations from nearly throughout the tropics, as well as several European hothouses, whereas $C$. villosus remains known only from Rotuma Island, Fiji, Pacific Ocean. In Africa, in addition to the Comoro and Seychelle islands off the eastern coast, $C$. hirsutus has only been recorded from a single main- land locality: Amani, a somewhat "synanthropic" habitat in the East Usambara Mountains, NE Tanzania [Enghoff, 1978]. As noted by Bergholz [2005], shifts from a parthenogenetic to a bisexual state and back seem to occur regularly in $C$. hirsutus, depending on environmental conditions: harsher habitats tend to support the thelytokous (male-free) form, while more favourable places tend to be populated by the bisexual form.

The present note puts on record C. hirsutus discovered in Cameroon for the first time. This is also a second Afrotropical locality found to support that species.

\section{Material and methods}

Most of the material treated here derives from the collection of the Musée Royal de l'Afrique Centrale (MRAC), Tervuren, Belgium, with only a few duplicates retained for the collection of the second author (ARNF), Cameroon or donated to the Zoological Museum, State University of Moscow (ZMUM), Russia. The samples are stored in $70 \%$ ethanol. Specimens for scanning electron microscopy (SEM) were air-dried, mounted on aluminium stubs, coated with gold and studied using a JEOL JSM-6480LV scanning electron microscope.

Taxonomic part

Cylindrodesmus hirsutus Pocock, 1889 Figs 1-9.

MATERIAL. $30^{7} \sigma^{7}, 37$ + $+9,23$ juv. (MRAC 22721), $10^{\top 7}$ (SEM, MRAC 22722),Cameroon, campus of University of Yaoundé 1, palm plantation, 7.IV.2015, leg. A.R. Nzoko Fiemapong. 

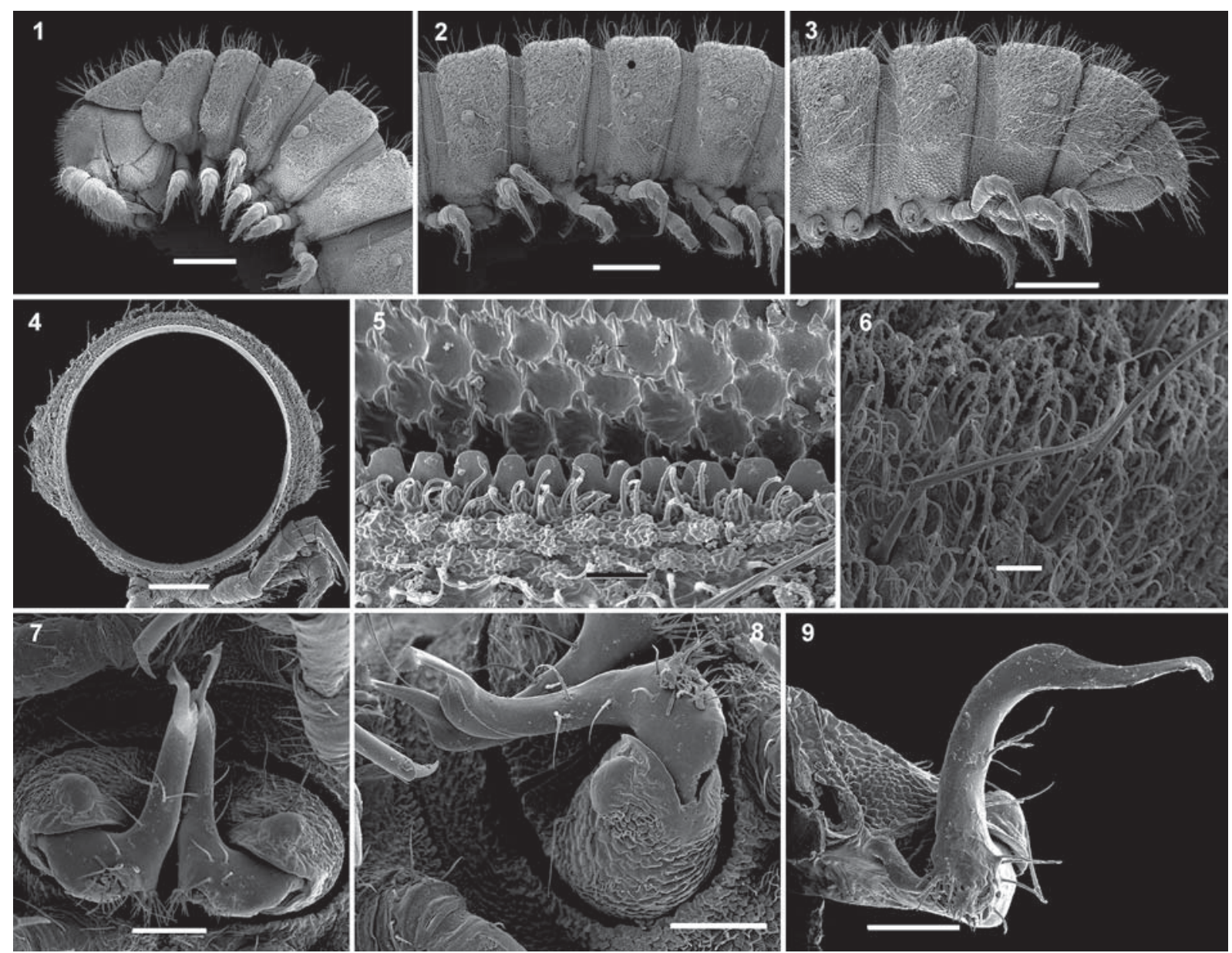

Figs 1-9. Cylindrodesmus hirsutus Pocock, 1889, $0^{7}$ from Yaoundé. 1 - anterior part of body, lateral view; 2 - midbody segments, lateral view; 3 - caudal part of body, lateral view; 4 - cross-section of a poriferous midbody segment, caudal view; 5 - fine structure of limbus and adjacent parts of tegument, dorsal view; 6 - tergal pilosity, dorsal view; 7 - both gonopods in situ, ventral view; 8 - right gonopod, lateral view, 9 - left gonopod, mesal view. Scale bars: 0.2 (1-3); 0.1 (4); 0.05 (7-9) and $0.01 \mathrm{~mm}(5-6)$.

Рис. 1-9. Cylindrodesmus hirsutus Pocock, 1889, О’ из Яунде. 1 - передняя часть тела, сбоку; 2 - среднетуловищные сегменты, сбоку; 3 - задняя часть тела, сбоку; 4 - поперечный срез через несущий озопору среднетуловищный сегмент; 5 - микроструктура лимбуса и прилегающих частей покровов, сверху; 6 - щетинки на тергитах, сверху; 7 - оба гонопода на месте, снизу; 8 - правый гонопод, сбоку; 9 - левый гонопод, изнутри. Масштаб: 0,2 (1-3); 0,1 (4); 0,05 (7-9) и 0,01 мм (5-6).

REMARKS. That this pantropical anthropochore diplopod has been found in an artificial plantation within a large city in western Africa is hardly surprising. More remarkable seems to be the sex ratio in the Yaoundé population which, however strongly biased to females, is not totally devoid of $\bigcirc^{7} \bigcirc^{7}$, i.e. likely bisexual. This might imply that the palm plantation in the university campus in Cameroon is a more favourable habitat for $C$. hirsutus than the one at Amani, Tanzania, whence not a single $\sigma^{7}$ was recorded among 55 specimens collected [Enghoff, 1978].

New illustrations (Figs 1-9) are provided to demonstrate the species' identity and make it easily recognizable.

ACKNOWLEDGEMENTS. Both ARNF and SIG are most grateful to the MRAC administration for the financial support rendered to make their joint research at MRAC possible in May 2017. The authors thank most heartily Christophe Allard (MRAC) for his technical assistance. ARNF is greatly obliged to the Rufford Foundation, grant No. 206871 and Congo Basin Grant Program (2016) which supported him financially during his field work in Cameroon. SIG is thankful to Kirill Mikhailov (Moscow) for the incorporation of ZMUM samples into the collection.

\section{References}

Bergholz N. 2005. The millipede Cylindrodesmus hirsutus (Pocock, 1889), new to the fauna of Costa Rica // Arthropoda Selecta. Vol.14. No.4. P.297-298.

Enghoff H. 1978. Cylindrodesmus laniger Schubart, a widespread, probably parthenogenetic millipede (Diplopoda, Polydesmida: Haplodesmidae) // Entomologica Scandinavica. Vol.9. P.80.

Golovatch S.I., Hoffman R.L., Knapinski S., Adis J. 2001. Review of the millipede genus Cylindrodesmus Pocock, 1889 (Diplopoda: Polydesmida: Haplodesmidae) // Fragmenta Faunistica. Vol.44. P.179-201. 